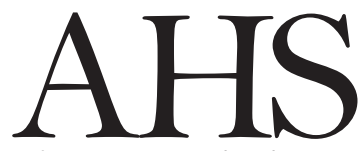

Advances in Horticultural Science

\title{
Endogenous hormone causes flower and fruit drop of wax apple (Syzygium samarangense cv. Citra)
}

\author{
E. Wukir Tini ${ }^{(*)}$, T.A. Dwi Haryanto, Sakhidin, Saparso \\ Agriculture Faculty, Jenderal Soedirman University, Purwokerto, Central \\ Java, Indonesia.
}

Key words: ACC, cytokinins, fruit drop, IAA, $\mathrm{GA}_{3}$, wax apple.

Abstract: The aim of this study was to obtain information about the content of endogenous hormones that causes flowers and fruit drop of wax apple. The variables observed in the six stages of flower and fruit development that drop easily and retention of indole-3-acetic acid (IAA), cytokinin (zeatin and kinetin), gibberellins $\left(\mathrm{GA}_{3}\right)$, 1-amino cyclopropane-1-carboxylic acid (ACC), total sugar, and starch. Six stages of development of wax apple fruit: (1) Bud Development (initial flowering) 0-3 days before anthesis. (2) Anthesis (perfect blooming flowers), 0-7 days after anthesis. (3) Fruit set, 7-14 days after anthesis. (4) Fruit development, 14-28 days after anthesis. (5) Fruit Maturation, 28-35 days after anthesis. (6) Fruit ripening, 35-50 days after anthesis. The results showed that the content of IAA, zeatin, $\mathrm{GA}_{3}$, and total sugar of flowers and fruit of wax apple at $\mathbf{6}$ stages that would fall smaller than those of retention and ACC content and starch was higher in flower and fruits that drop easily than retention. The kinetin content in the flower development that drop easily is smaller than the retention but in the fruit development the kinetin content is not significantly different between those that drop easily and retention.

Copyright:

(C) 2021 Wukir Tini E., Dwi Haryanto T.A., Sakhidin, Saparso. This is an open access, peer reviewed article published by Firenze University Press (http://www.fupress.net/index.php/ahs/) and distributed under the terms of the Creative Commons Attribution License, which permits unrestricted use, distribution, and reproduction in any medium, provided the original author and source are credited.

Data Availability Statement:

All relevant data are within the paper and its Supporting Information files.

Competing Interests:

The authors declare no competing interests.

\section{Introduction}

Water apple originates from the Southeast Asian region (Indonesia and Malaysia), then spreads to the islands of the Pacific and North and Central America. Generally, wax apple fruit is consumed as fresh fruit, but it can also be made for salad and preparations such as pickles, syrups, jellies, and cocktails. Water apple fruit is not only sweet and refreshing but has diversity in appearance. Types of water apple are Syzygium aqueum (water apple) and Syzygium samarangense (wax apple). The varieties of Syzygium samarangense include Delima, Lilin, Camplong, Cincalo, Citra, Kesuma, and Madu, (Kuswandi, 2008).

Corona Virus Disease (COVID-19) is originating from Wuhan, China began to spread throughout the world from January 2020 to 31 December 2020, so there were 83,264,353 cases, with $1,816,164$ deaths from 218 affected countries (World Health Organization, 2020). No vaccine has been found to treat patients with the COVID-19 virus. According 
to the Ministry of Health of the Republic of Indonesia (2020), prevention of viruses can be done by frequently washing hands, wearing masks, consuming vegetables and fruit, exercise, and adequate rest. One of the prevention efforts that can be done by consuming fruits that contain Vitamin $C$ to enhance immunity. Every $100 \mathrm{~g}$ of wax apple fruit contains $22.3 \mu \mathrm{g}$ of vitamin C (Asia-Pacific Association of Agricultural Research Institutions, 2014). Therefore wax apple is a tropical fruit that is cheap, easily obtained, and contains vitamin $C$ which can be used as an alternative to increasing body immunity as a preventative measure against the COVID-19 virus.

The main problem in the cultivation of wax apple plants is the high drop of flowers and fruit. The high rate drop of flowers and fruit causes a few numbers of wax apple fruit that can be produced. Wax apple drop fruit rate reaches 52\% (Khandaker et al., 2016). Fruit drop also occurs in other fruits, such as durian flowers reach 95 to $100 \%$ (Suparto and Sakhidin, 2013), lychee fruit is 90 to $97 \%$ (Stern et al., 1995), star fruit is 25 to $30 \%$ (Kurniawati and Hamim, 2009), mangosteen flower is $14.1 \%$ and mangosteen fruit is 70.1\% (Rai et al., 2008).

Dropped fruit is a natural phenomenon that occurs in almost all types of fruit. Drop fruit, especially at the beginning of fruit growth, is a mechanism for regulating autoregulation in each plant (Davarynejad et al., 2009). Physiologically the loss of flowers and fruit correlates with the limited supply of photosynthate and nutrient adequacy (Iglesias et al., 2007), as well as hormonal regulation in the abscission zone (Bangerth, 2000). Flower and fruit drop are also influenced by endogenous hormone content in plants due to high ethylene concentrations and low concentrations of auxin and gibberellins. Auxin, gibberellins, and ethylene are hormones that are directly related to the process of flowers and fruit drop (Bangerth, 2000). Complex hormonal interactions occur during fruit development. Gibberellins and cytokines generally stimulate fruit growth and auxin as a growth stimulator and also as a fruit drop agent. Abscisic acid (ABA) and ethylene are also involved in the process of loss (Sakamoto et al., 2008). High ethylene concentrations, low concentrations of auxin and gibberellins, and high $A B A$ concentrations in plants are the main causes of drop fruit (Iglesias et al., 2007).

The causes of flower and fruit drop of the wax apple due to imbalance of plant growth regulator as well as cultivation and environmental engineering factors, including pollination, fertilization, fruits set, lack of water and nutrition supply, pest attack, rainfall and wind (Khandaker et al., 2016). Research on the use of synthetic Growth Plant Regulators (GPR) to reduce the fruit drop of wax apple has been conducted by Khandaker et al. (2013), Khandaker et al.

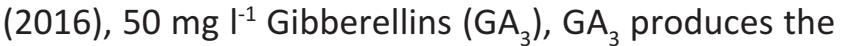
lowest flower and fruit buds loss of $29 \%$ compared to controls (not given $\mathrm{GA}_{3} 36 \%$ ). GA3 $20 \mathrm{mg} \mathrm{l}^{-1}$ reduced fruit loss $32 \%$ compared to $52 \%$ control. 2-4Dichlorophenoxyacetid (2,4 D) $5 \mathrm{mg} \mathrm{l}^{-1}$ reduces flower and fruit bud loss by at least $30 \%$ and $18 \%$ compared to $35 \%$ and $40 \%$ controls. Naphthaleneacetid Acid (NAA) $5 \mathrm{mg} \mathrm{l}^{-1}$ reduced the flower buds and fruits drop as lower as $28 \%$ and $30 \%$ compared to $30 \%$ and $52 \%$ controls. The causes of flowers and fruit drop of wax apple are because the content of endogenous hormones is not yet known, so the application of growth plant regulator given is not appropriate to reduce the flowers and fruit drop.

Singh et al. (2017) the results of research on the application of growth plant regulator on Khasi mandarin (Citrus reticulata Blanco) showed an increase in fruit retention and the number of fruit with the application of Urea $1 \%+2$, 4-D 15 ppm (45.4\% and 244, 3 fruits/tree), application of NAA 5 ppm + 2,4-D 10 ppm (44.3\% and 241.6 fruit/tree) compared to controls (17.3\% fruit retention and 181 fruit/tree). NAA treatment $15 \mathrm{ppm}$ increased the proportion of cape gooseberry cv. Aligarh is retention (71.40\%) (Kaur and Kaur, 2016).

The purpose of this study was to obtain information on hormones that causes flower and fruit drop at several stages of the development of wax apple fruit and to obtain differences in the hormone content at how many stages of flower and fruit development are easily dropped and retention.

\section{Materials and Methods}

The research used an experimental method from May 2019 to April 2020. The experimental design used was a Completely Randomized Design (CRD) with the treatment being tried, namely flower and fruit retention and drop easily of wax apple at six stages fruit development: (1) Bud development (from 0 to 7 days before anthesis); (2) Anthesis (full bloom), from 0 to 7 days after anthesis; (3) Fruit set (the formation of finished fruit), from 7 to 14 days after anthesis; (4) fruit development, from 14 to 28 days after anthesis; (5) Fruit maturation, from 28 to 35 
days after anthesis; (6) Fruit ripening (from 35 to 50 days after anthesis). Experiment with 4 replications and data analysis using t-test and advanced test DMRT (Duncan Multiple Range Test). Flower and fruit samples were taken from 46 wax apple plants, Kajongan Village, Bojongsari District, Purbalingga Regency, Central Java. The variables observed were auxin content (IAA), cytokinins (zeatin and kinentin), gibberellin (GA3), ACC (1-Aminocyclopropane 1Carboxylic Acid), total sugar, and starch.

The samples used for the study were flowers and fruits from 6 stages of development of flowers and water guava. Plants are 5 years old, plant spacing $8 \mathrm{~m}$ $\times 9 \mathrm{~m}$, with a height of $\pm 7 \mathrm{~m}$ and have been fruiting for the last 4 years. Temperature $25.8^{\circ} \mathrm{C}$ with $76 \%$ humidity, sunlight intensity 571 Lux outside the canopy, and under the canopy 529 Lux and soil pH 6.8. Organic cultivation of wax apple uses goat manure at a dose of $100 \mathrm{Kg}$ per plant per year. Irrigation in the dry season with springs that are channeled from a hose from a pipe made by the garden. The results of soil analysis conducted at the Postharvest Center of the Ministry of Agriculture, inceptisol soil type, $\mathrm{pH} 6.14$, organic $\mathrm{C} 0.769 \%$, total $\mathrm{N} 0.082 \%$, available N $0.025 \%$, total $\mathrm{K} 55.960$ ppm, K available $30.277 \mathrm{ppm}$, total P $45.189 \mathrm{ppm}$, and $1.321 \%$ organic matter.

The samples drop easily are taken from the flower and fruit which when the branches or twigs are shaken fall out and after the fall there is a black abscission layer on the flower stalk or fruit. The retention samples are wax apple flower and fruit which if the branches or twigs are shaken not fall off, are still attached to the plant, and usually, the flower stalk or fruit is still present. The sample is placed in an icebox containing blue ice and then taken to the Integrated Research Laboratory, Jenderal Soedirman University to be dried in a $2 \mathrm{kxc}$ bench top Vacuum Freeze Dryer. Wax apple samples for bud development, anthesis, and fruit set for 25 hours, and fruit development, fruit maturation, fruit ripening for 55 hours with a temperature of $-70^{\circ} \mathrm{C}$, and a pressure of $13,332.2 \mathrm{~Pa}$ The contents of auxin (IAA), GA ${ }_{3}$, zeatin, kinetin, ACC, total sugar, and starch were carried out at the Chemical Laboratory, Center for Postharvest, Ministry of Agriculture, Bogor, West Java, Indonesia.

Procedure for measuring hormone content (auxin, cytokinin, and gibberellins) using HPLC (HighPressure Liquid Chromatography) at a wavelength of $214 \mathrm{~nm}$, sample temperature of $10^{\circ} \mathrm{C}$ and column temperature of $25^{\circ} \mathrm{C}$, stationary phase using $\mathrm{C}-18$.
The formula for hormone content by HPLC is sample area divided by standard area multiplied by standard concentration (Harborne, 1973). Measurement of ACC content according to Lizada and Yang (1979), using GC (Gas Chromatography). The formula for ACC content in GC is sample area divided by standard area multiplied by standard concentration. Measurement of total sugar according to the Indonesian National Standard (1992) using the Luff Schoorl method. Starch calculation according to Horwitz and Latimer (2006).

\section{Results}

Table 1 shows that the fruit drop easily having lower IAA, zeatin, and $\mathrm{GA}_{3}$ content than fruit retention in all phases of fruit development. The kinetin content at the bud development, anthesis, and fruit set stages that drop easily is lower than the retention, but the kinetin content at the fruit development, fruit maturation and fruit ripening stages is not significantly different in the fruit that drop easily dan retention. While the ACC content of fruit that drops easily is greater than that of retention.

Table 2 shows that the total sugar content at various stages of flower and wax apple fruit development in flower and fruit retention is higher than that of drop easily. The content of starch in fruit retention of various stages of development of the flower and fruit is lower than those that are of drop easily.

\section{Discussion and Conclusions}

The IAA content in wax apple flower and fruit which drops easily on bud development, anthesis, fruit set, fruit development, fruit maturation, and fruit ripening is lower than the retention flower and fruit. This is according to Rai et al. (2008). The IAA content of mangosteen flowers falling $3.37 \mathrm{ng} \mathrm{g}^{-1}$ is lower than the retention rate of $8.80 \mathrm{ng} \mathrm{g}^{-1} \mathrm{dry}$ weight and IAA content in mangosteen fruit falling $0.83 \mathrm{ng} \mathrm{g}^{-1}$ is lower from the IAA content of $6.43 \mathrm{ng}$ $\mathrm{g}^{-1}$ retention fruit. Sakhidin et al. (2011), the content of IAA in mango fruit loss is lower than that of retention. Gadung 21 and Lali Jowo cultivars that will fall age 6 and 9 days after anthesis are 5.96 and $3.8610^{-1}$ $\mu \mathrm{g} \mathrm{g}{ }^{-1}$ sample fresh weight and 4.48 and $4.1210^{-1} \mu \mathrm{g}$ $\mathrm{g}^{-1}$ sample fresh weight. Mango fruit retention of 10.32 and $8.12\left(10^{-1} \mu g^{-1}\right.$ sample fresh weight and 
Adv. Hort. Sci., 2021 35(1): 53-60

Table 1 - The content of several hormones at the stage of development fruit of wax apple var. Citra

\begin{tabular}{|c|c|c|c|c|c|c|}
\hline \multirow[b]{2}{*}{ Treatment } & \multicolumn{6}{|c|}{ Flower and fruit development } \\
\hline & $\begin{array}{c}\text { Bud } \\
\text { development }\end{array}$ & Anthesis & $\begin{array}{l}\text { Fruit } \\
\text { Set }\end{array}$ & $\begin{array}{c}\text { Fruit } \\
\text { development }\end{array}$ & $\begin{array}{c}\text { Fruit } \\
\text { maturation }\end{array}$ & $\begin{array}{c}\text { Fruit } \\
\text { Ripening }\end{array}$ \\
\hline \multicolumn{7}{|l|}{ IAA (ppm) } \\
\hline Retention & $69.50 \mathrm{a}$ & $33.72 \mathrm{a}$ & $47.40 \mathrm{a}$ & $57.02 \mathrm{a}$ & $42.86 \mathrm{a}$ & $42.10 \mathrm{a}$ \\
\hline Drop easily & $1.42 \mathrm{~b}$ & $0.73 \mathrm{~b}$ & $0.68 b$ & $1.22 \mathrm{~b}$ & $0.78 \mathrm{~b}$ & $0.41 b$ \\
\hline \multicolumn{7}{|l|}{ Zeatin (ppm) } \\
\hline Retention & $2.18 \mathrm{a}$ & $2.25 \mathrm{a}$ & $3.29 \mathrm{a}$ & $2.19 \mathrm{a}$ & $2.59 \mathrm{a}$ & $2.04 \mathrm{a}$ \\
\hline Drop easily & $0.17 \mathrm{~b}$ & $0.50 \mathrm{~b}$ & $0.66 \mathrm{~b}$ & $0.36 \mathrm{~b}$ & $0.03 \mathrm{~b}$ & $0.46 \mathrm{~b}$ \\
\hline \multicolumn{7}{|l|}{ Kinetin (ppm) } \\
\hline Retention & $4.36 \mathrm{a}$ & $2.46 \mathrm{a}$ & $11.31 \mathrm{a}$ & $3.17 \mathrm{a}$ & $3.30 \mathrm{a}$ & $3.93 \mathrm{a}$ \\
\hline Drop easily & $2.16 b$ & $1.38 \mathrm{~b}$ & $2.96 \mathrm{~b}$ & $3.05 \mathrm{a}$ & $2.75 \mathrm{a}$ & $2.39 \mathrm{a}$ \\
\hline \multicolumn{7}{|l|}{ GA3 (ppm) } \\
\hline Retention & 79.65 a & $68.08 \mathrm{a}$ & $90.47 \mathrm{a}$ & $68.25 \mathrm{a}$ & $63.45 \mathrm{a}$ & $57.72 \mathrm{a}$ \\
\hline Drop easily & $28.63 \mathrm{~b}$ & $16.13 \mathrm{~b}$ & $20.14 b$ & $26.69 \mathrm{~b}$ & $17.57 \mathrm{~b}$ & $8.97 \mathrm{~b}$ \\
\hline \multicolumn{7}{|l|}{$A C C(p p m)$} \\
\hline Retention & 19.18 b & $17.26 \mathrm{~b}$ & $14.21 b$ & $14.13 b$ & $13.31 b$ & $12.14 b$ \\
\hline Drop easily & 48.39 a & 38.09 a & 37.99 a & $35.75 \mathrm{a}$ & $34.14 a$ & 30.92 a \\
\hline
\end{tabular}

The number followed by the same letter in the same column for each fruit development is not significantly different from the t-test at $p<0.05$.

Table 2 - Total sugar content and starch content on stages of wax apple flower and fruit development

\begin{tabular}{|c|c|c|c|c|c|c|}
\hline \multirow[b]{2}{*}{ Treatment } & \multicolumn{6}{|c|}{ Flower and fruit development stage } \\
\hline & $\begin{array}{c}\text { Bud } \\
\text { development }\end{array}$ & Anthesis & $\begin{array}{l}\text { Fruit } \\
\text { set }\end{array}$ & $\begin{array}{c}\text { Fruit } \\
\text { development }\end{array}$ & $\begin{array}{c}\text { Fruit } \\
\text { maturation }\end{array}$ & $\begin{array}{c}\text { Fruit } \\
\text { ripening }\end{array}$ \\
\hline \multicolumn{7}{|c|}{ Total sugar content (\%) } \\
\hline Retention & 6.87 a & $8.72 \mathrm{a}$ & $11.38 \mathrm{a}$ & $23.35 \mathrm{a}$ & $28.93 \mathrm{a}$ & $32.59 \mathrm{a}$ \\
\hline Drop easily & $5.80 \mathrm{~b}$ & $7.60 \mathrm{~b}$ & $8.60 \mathrm{~b}$ & $20.61 b$ & $26.36 \mathrm{~b}$ & $28.66 \mathrm{~b}$ \\
\hline \multicolumn{7}{|c|}{ Starch content (\%) } \\
\hline Retention & $17.23 \mathrm{~b}$ & $16.29 \mathrm{a}$ & $14.52 \mathrm{~b}$ & $13.11 \mathrm{~b}$ & $11.02 \mathrm{~b}$ & $8.77 \mathrm{~b}$ \\
\hline Drop easily & $17.90 \mathrm{a}$ & $16.40 \mathrm{a}$ & $15.80 \mathrm{a}$ & $13.89 \mathrm{a}$ & $12.62 \mathrm{a}$ & $11.21 \mathrm{a}$ \\
\hline
\end{tabular}

The number followed by the same letter in the same column each fruit development is not significantly different in the t-test at the level of $p<0.05$.

10.08 and $7.9810^{-1} \mu g^{-1}$ sample fresh weight. According to Kurniawati and Hamim (2009), star fruit with an application of 15 ppm 2, 4-dichlorophenoxyacetic acid (2,4-D) contains $227 \mathrm{ppm}$ IAA and $60 \mathrm{ppm}$ $\mathrm{GA}_{3}$ applications have 221 ppm IAA.

The formation of the absicission layer at the stem point that causes fruit drop is an imbalance of auxin, cytokinin, and gibberellins (Chen et al., 2006). Flower and fruit loss is also influenced by high ethylene concentrations and low IAA type auxin concentrations and low gibberellins. Auxin and ethylene are hormones that are directly related to the process of a drop of flowers and fruit (Bangerth, 2000).

Auxin is often reported to delay or to induce fruit, it increases cell enlargement rather than cell division. This observation might indicate that auxin is related to cell enlargement, an essential factor controlling fruit size during the rapid fruit growth phase. Enlargement of fruits treated with auxin seems to be due to cell expansion rather than cell division (Iglesias et al., 2007).

Table 1 shows that the content of zeatin type cytokinins and fruit kinetin that drop easily is smaller than retention. This is because cytokinins function to inhibit aging (Kieber and Schaller, 2018) so that the flowers and fruits of wax apple which will fall at several stages of development have a smaller zeatin content compared to the retention seen in table 1 . The cytokinin content of both zeatin and kinetin at the stage of development flowers and fruit of wax apple was the highest at the fruit set stage. According to Chen (1983), the cytokinin content 
increased in mango flowers maximum at 10 days after anthesis and decreased gradually up to 50 days after anthesis. This is consistent with Trueman (2011), that high cytokinin concentrations in macadamia fruit are retention. Cytokinins are produced in roots and young fruit (Pratima and Chawla, 2019).

Table 1 shows that the $\mathrm{GA}_{3}$ content in several stages of flower and fruit development will fall lower than the retention of flowers and fruit. The GA3 content in fallen fruit was lower than that in retention (Bains et al., 1997). The role of GA3 is able to stimulate plant growth and flowering, increase flowering and reduce drop flower (Budiarto and Wuryaningsih, 2007). According to Kurniawati and Hamim (2009), gibberellin and auxin can support fruit retention by inducing the enzyme $\alpha$-amylase to hydrolyze starch to sugar that is needed for fruit growth and development (Subiyanto, 1991). This can be seen in Table 1 that the increased auxin content also increases the gibberellin content in retention flowers and fruits compared to drop easily and in Table 2 flowers and fruits retention have a higher total sugar content than drop easily.

The ACC content of wax apple flowers and fruits that drop easily is higher than the retention of flowers and fruits are seen in Table 1. This is because the ACC which is an ethylene precursor makes the drop of flowers or fruits become higher (Wang et al., 2002). The mango ACC content that drops easily is higher than that of retention (Sakidin et al., 2011). The ACC content of Gadung 21 and Lali Jiwo cultivars which drop easily higher at the age of $3,9,12$ days after anthesis are 26.81, 35.78, $43.41\left(10^{-1} \mathrm{mg} \mathrm{g}^{-1}\right)$ sample fresh weights and 29.13, 29.35, $35.79\left(10^{-1}\right.$ $\mathrm{mg} \mathrm{g}^{-1}$ ) sample fresh weight. The ACC content of Gadung 21 and Lali Jiwo cultivars with age retention of $3,9,12$ days after anthesis is $26.81 ; 35.78 ; 43.41$ $\left(10^{-1} \mathrm{mg} \mathrm{g}^{-1}\right)$ fresh sample weights and $10.13 ; 13.66$; $11.94\left(10^{-1} \mathrm{mg} \mathrm{g}^{-1}\right)$ sample fresh weights (Sakhidin et al., 2006).

Flower and ovary abscission occur in AZ-A (Abscission Zone) located between branches and flower stalks. Absence in the AZ-A zone starts from the fruit set period and this negative effect is regulated by the content of gibberellins in the ovaries. Fruitlet abscission during fruit drop in June at the end of the fruitset period on AZ-C which is located in the petals, between the flower disks and the ovarian wall, and highly dependent on carbohydrate availability. Sugar in mature leaves is transported for fruit- let growth and activates AZ-C (Iglesias et al., 2007).

According to Iglesias et al. (2007), the lack of carbon in fruitlets induces an increase in abscisic acid (ABA) and ACC (1-Aminocyclopropane 1-Carboxylic Acid) which are ethylene precursors. These precursors are then oxidized to ethylene $\left(\mathrm{C}_{2} \mathrm{H}_{4}\right)$ and release of gases that cause fruit abscission. In contrast to the development of fruitlets, in the process of cooking the fruit accumulation of sugar in ripe fruit has a role to induce the activation of abscission before harvest. The balance between $\mathrm{C}_{2} \mathrm{H}_{4}$ as a process accelerator, and auxin (AUX) as an inhibitor, is one of the main factors in the regulation of ripe fruit abscission. Synthesis of auxin in young leaves and transported to adult fruit as an inhibition inhibitor that protects $A Z$ from high $\mathrm{C}_{2} \mathrm{H}_{4}$ content. The role of the regulation of jasmonic acid (JA) in fruit reduction is thought to be mediated through the stimulation of $\mathrm{C}_{2} \mathrm{H}_{4}$ biosynthesis. The balance between AUX and $A B A$ in mature fruits is also important in determining the sensitivity of AZ-C for abscission stimulus because ACC is an ethylene precursor (Wang et al., 2002).

Fruit abscission that occur during fruit development due to the active abscission zone. The process is induced by several environmental factors, competition in the use of assimilates, and internal hormone content. The abscission zone on the mango is located on the fruit stalk with a distance of several $\mathrm{mm}$ from the fruit concave (where the fruit is attached to the fruit stalk). From the biochemical and molecular aspects, abscission occurs due to the active enzyme ß-1,4-endoglucanase (EG) and polygalacturonase $(P G)$. The two hydrolase enzymes are involved in damage to plant cell walls that are responsible for the drop of flowers and fruits. The specificity of the abscission zone in responding to organ drop depends on the sensitivity of the layer to ethylene (Bonghi et al., 2000).

Control of fruit growth and abscission in oranges is due to three regulatory factors: genetic, metabolic, and environmental. All three of these affect hormonal signals in citrus plants (Iglesias et al., 2007). Overall, these studies show that a complex set of hormonal interactions occur during fruit development. Thus, gibberellins (GAs) and cytokinins are generally considered positive fruit growth regulators while auxin has been reported to act as a growth stimulator and also as an abscess agent. Abscisic acid $(A B A)$ and ethylene have been involved in several ways in an abscess. Concentrations of IAA and GA3 in fruit and fruit stalks that drop easily are lower than 
those in fruit retention and fruit stalks, fruits that will fall out have high abscisic acid content. Drop fruit is also caused by an increase in ethylene production.

Table 2 shows that the flower and fruit drop had a lower total sugar content but a higher starch content than the retention. This is following Stopar et al. (2001), apples that drop easily have higher starch content and lower sugar content compared to retention. Mangoes that pre-abscission have a lower total sugar content and a higher starch than retention (Sakhidin et al., 2011).

Total sugar content in flower and fruit development of wax apple var. Citra of bud development, anthesis, fruit set, fruit development, fruit maturation, and fruit ripening stages 5.8, 7.6, 8.6, 20.16, $26.36,28.66 \%$ lower in fruits that drop easily with fruit retention of $6.87,8.72,11.38,23.35,28.93$, $32.59 \%$. This is in accordance with Rai et al., (2008), carbohydrate content (total sugar) in leaves in flower branches and mangosteen fruit which is lower (40.3 and $52.3 \mathrm{mg} \mathrm{g}^{-1}$ leaf dry weight) compared to leaves in branches that are flower and fruit retention (41.2 and $59.1 \mathrm{mg} \mathrm{g}^{-1}$ leaf dry weight). The retention of glucose, fructose, and inverted sugar of wax apple fruit was as follows: $8.9 \%, 8.9 \%, 8.7 \%$ var. Giant Green, $9.83 \%, 9.9 \%, 9.6 \%$ var. Masam manis pink, and 9.61\%, 9.6\%, 9.3\% var Madu red (Khandaker et al., 2011). This shows that the drop of flowers and fruit is associated with a low supply of carbohydrates. Limited carbohydrate sources affect the formation and development of fruit (Pawar and Rana, 2019).

Increasing the rate of photosynthesis is very important to produce carbohydrates during the development of fruit sets (Iglesias et al., 2002). The limited supply of photosynthate and nutritional status of plants can limit the number of flowers that develop into fruit that can be harvested (Rai et al., 2008). In oranges, carbohydrate deficiencies produce young fruit abscess by triggering an increase in ACC levels (Gómez-Cadenas et al., 2000). Auxin applied to trees that have yellow leaves due to low carbohydrate cannot prevent pre-harvest loss (Sakhidin et al., 2006).

Table 2 shows that the starch content in flower and fruit development stages of bud development, anthesis, fruit set, fruit development, fruit maturation, and fruit ripening 16.29, 14.52, 13.11, 11.02, $8.77 \%$ in fruit retention. The starch content in wax apple is getting smaller as the fruit develops. According to Mureşan et al. (2015), the starch content was reduced in the early stages of fruit develop- ment in the 3 apple varieties studied, then the starch concentration increased significantly from 35 to 65 days after anthesis. Starch concentration gradually decreases as the fruit ripens. This can be seen in Table 2 that the starch content during the development of the wax apple fruit is seen to decrease from flower buds to fruit maturity, and in fruits that drop easily the starch content is higher than that of retention.

It was concluded the content of IAA, zeatin, kinetin, $\mathrm{GA}_{3}$, and total sugars at several stages of the flower and fruit wax apple which drop easily lower than that of retention and the ACC content and starch are higher in fruit which drops easily than retention. The endogenous hormone content of wax apple flower and fruit that drop easily are as follows IAA 0.41 to $1.42 \mathrm{ppm}$, zeatin 0.03 to $0.66 \mathrm{ppm}$, kinetin 1.38 to $2.96 \mathrm{ppm}, \mathrm{GA}_{3} 8.97$ to $28.63 \mathrm{ppm}$, and ACC 30.92 to $48.39 \mathrm{ppm}$. The wax apple fruit that retention IAA content of 30.92 to $48.39 \mathrm{ppm}$, zeatin 2.04 to $3.29 \mathrm{ppm}$, kinetin 2.46 to $11.31 \mathrm{ppm}, \mathrm{GA} 3$ 57.72 to $79.65 \mathrm{ppm}$, and ACC 30.92 to $48.39 \mathrm{ppm}$. The total sugar content of wax apple flower and fruit which drop easily from 5.8 to $28.66 \%$ is lower than the retention rate of 6.87 to $32.59 \%$. The content of fruit starch that drops easily is 11.21 to $17.9 \%$ higher than the retention of 8.77 to $17.23 \%$. Actions that can be taken to prevent the drop of wax apple fruit by giving natural endogenous hormones contained in other plant materials. This can be done after knowing the content of auxin, zeatin, kinetin, gibberellins, and ACC in wax apple fruit that drop easily or retention.

\section{Acknowledgements}

The research was supported by research funds from the Directorate of Research and Community Service, Ministry of Education and Culture Doctoral Dissertation Research Scheme for the 2020 Budget Year through a Decree of the Chairperson of the Research and Community Service Institute, Jenderal Soedirman University Number: Kept. 631/UN23.18/ PT.01.05/ 2020.

\section{References}

ASIA PACIFIC ASSOCIATION OF AGRICULTURAL RESEARCH INSTITUTIONS, 2014 - Wax apple industry in Taiwan: A success story. - Asia Pacific Association of Agricultural 
Research Institutions, Bangkok, Thailand, pp. 48.

BAINS K.S., BAJWA G.S., SINGH Z., 1997 - Abscission of mango fruitlet I in relation to endogen concentration of $I A A, G A 3$ and $A B A$ in pedicels and fruitlets. - Fruit Paris, 52(3): 159-165.

BANGERTH F., 2000 - Abscission and thinning of young fruit and their regulation by plant hormones and bioregulators. - Plant Growth Regulator, 31: 43-59.

BONGHI C., TONUTTI P., RAMINA A., 2000 - The biochemical and molecular aspect of fruitlet abscission. - Plant Growth Regulator, 31: 35-43.

BUDIANTO K., WURYANINGSIH S., 2007 - Respon Pembungaan Beberapa Kultivar Anthurium Bunga Potong. - Agritrop., 26(2): 51-56.

CHEN H., DEKKERS K.L., CAO L., BURNS J.K., TIMMER L.W., CHUNG K., 2006 - Evaluation of growth regulator inhibitors for controlling postbloom fruit drop (PFD) of citrus induced by fungi in Colletotrichum acutatum. Hort. Sci., 4(5): 317-321.

CHEN W.S., 1983 - Cytokinins of the developing mango fruit' isolation, identification, and changes in levels during maturation. - Plant Physiol., 71: 356-361.

DAVARYNEJAD G.H., NYEKI J., TORNYAI J., SZABO Z., SOLTESZ M., 2009 - The terminology of fruit set and fruit drop of sour cherry cultivars. - Inter. J. Hortic. Sci., 15(4): 33-36.

GÓMEZ-CADENAS A., MEHOUACHI J., TADEO F.R., PRIMOMILLO E., TALON M., 2000 - Hormonal regulation of fruitlet abscission induced by carbohydrate shortage in citrus. - Planta, 210: 636-643.

HARBORNE J.B., 1996 - Metode Fitokimia. Cara modern menganalisa Tumbuhan. - Terjemahan Kosasih Patmawinata dan Iwang Soediro. Edisi ke 3. Penerbit ITB. Bandung,pp. 354.

HORWITZ W., LATIMER G.W., 2006 - Official Methods of Analysis of AOAC International. - Publisher by AOAC International, Washington, USA, Chapter 37.1.54, pp. 19.

IGLESIAS D.J., CERCÓS M., COLMENERO-FLORES J.M., NARANJO M.A., RÍOS G., CARRERA E., RUIZ-RIVERO O., LLISO I., MORILLON R., TADEO F.R., MANUEL T., 2007 Physiology of citrus fruiting. - Brazilian J. Plant Physiol., 19(4): 333-362.

IGLESIAS D.J., LLISO I., TADEO F.R., TALON M., 2002 Regulation of photosynthesis through source: sink imbalance in citrus is mediated by carbohydrate content in leaves. - Physiology Plant., 116: 563-569.

INDONESIAN NATIONAL STANDARDS, 1992 - How to test sugar. - National Standardization Agency., SNI 01-28921992.

KAUR G., KAUR A., 2016 - Plant growth and fruit yield attributes of cape gooseberry cv. Aligarh as affected by the use of different growth regulators. - Agric. Sci. Digest., 36(2): 138-141.

KHANDAKER M.M., AL-SAIF A.M., ALEBIDI A.I., HOSSAIN A.B.M.S., NORMANIZA O., BOYCE A.N., 2011 - An evalu- ation of the nutritional quality evaluation of three cultivars of Syzygium samarangense under Malaysian conditions. - African J. Agric. Res., 6(3):545-552.

KHANDAKER M.M., BOYCE A.N., OSMAN N., GOLAM F., RAHMAN M.M., SOFIAN-AZIRUN M., 2013 - Fruits Development, pigmentation, and biochemical properties of wax apple as affected by localized application of $\mathrm{GA}_{3}$ under field condition. - Braz. Arch Biol. Tecnol., 56(1): 11-20.

KHANDAKER M.M., IDRIS N.S., ISMAIL S.Z., MAJRASHI A., ALEBEDI A.I., MAT N., 2016 - Cause and prevention of fruit drop of Syzygium samarangense (wax apple): $A$ review. - Adv. Environ. Biol., 10(11): 112-123.

KIEBER J.J., SCHALLER G.E., 2018 - Cytokinin signaling in plant development. - Development, 145: 1-7.

KURNIAWATI B., HAMIM, 2009 - Physiological Responses and Fruit Retention of Carambola Fruit (Averrhoa carambola L.) Induced by 2,4-D and $G A_{3}$. - Hayati Journal of Biosciences, 16(1): 9-14.

KUSWANDI, 2008 - Technical guidelines for seed production clonal of Java apple - Indonesian Tropical Fruit Research Institute, North Sumatra, pp. 39.

KLIZADA M.C.C. YANG S.F., 1979 - A simple and sensitive assay for 1-amino cyclopropane-1-carboxylic acid. Anal. Biochem., 100: 140-145.

MINISTRY OF HEALTH OF THE REPUBLIC OF INDONESIA., 2020 - Prepared for the coronavirus novel. Retrieved March 18, 2020, from https://www.kemkes.go.id/article/view/20012900002/ Preparedness- FacingInfection-Novel-Coronavirus.html.

MUREŞAN E.A., MUSTE S., VLAIC R.A., MUREŞAN C.C., 2015 - The dynamics of starch and total sugars during fruit development for ionathan, starkrimson, and golden delicious apple varieties. - Bulletin of University of Agricultural Sciences and Veterinary Medicine ClujNapoca, Food Science and Technology, 72(1): 120-126.

PAWAR R., RANA V.S., 2019 - Manipulation of source-sink relationship in pertinence to better fruit quality and yield in fruit crops: A review. - Agric. Reviews, 40(3): 200-207.

PRATIMA P., CHAWLA W., 2019 - Influence of plant growth regulators on growth and yield of pome and stone fruits. - J. Pharmacognosy and Phytochemistry, SP1: 557-565.

RAI I.N., POERWANTO R., DARUSMAN L.K., PURWOKO B.S., 2008 - ABA, IAA, and carbohydrate in relation to flower and fruit drop on mangosteen. - Paper in 4th International Symposium on Tropical and Subtropical Fruits. November 3-7, 2008, Bogor, West Java, Indonesia, pp. 1-8.

SAKAMOTO M., MUNEMURA I., TOMITA R., KOBAYASHI K., 2008 - Reactive oxygen species in leaf abscission signaling. - Plant Signal Behavior, 3(11): 1014-1015.

SAKHIDIN PURWOKO B.S., TEIXEIRA DA SILVA J.A., POERWANTO R., SOESANTO S., 2011 - Indole-3-acetic acid, 1-amino cyclopropane1-carboxylic acid, and car- 
bohydrate in relation to fruit drop on mango tree. - J. Fruit Ornam. Plant Res., 19(2): 41-49.

SAKHIDIN PURWOKO B.S., YAHYA S., POERWANTO R., SUSANTO S., ABIDIN U.S., 2006 - The content of some endogenous substances in fruit retention and fruit drop easily on mangoes. - Agron. Bulletin, 34(2): 106 -111.

SINGH S.R., WANGCHU L., SINGH B., HAZARIKA B.N., PANDEY A.K., 2017 - Effect of PGRs combination on pre-harvest fruit drop of Khasi mandarin (Citrus reticulata Blanco.). - Indian J. Agric. Res., 51(2): 167-172.

STERN R.A., KIGEL J., TOMER E., GAZIT S., 1995 'Mauritius' lychee fruit development and reduced abscission after treatment with the auxin 2,4,5-TP. - J. Amer. Soc . Hort . Sci., 120(1): 65-70.

STOPAR M., RESNIK M., PONGRAC V.Z., 2001 - Non-structural carbohydrate status and $\mathrm{CO}_{2}$ exchange rate of apple fruitless at the time of abscission influenced by shade, NAA or BA. - Sci. Hort. (Amsterdam), 87: 65-76.
SUBIYANTO H.S., 1991 - Fisiologi Tanaman Budidaya. Universitas Indonesia Jakarta.

SUPARTO S.R., SAKHIDIN, 2013 - Study of deciduous durian fruit and efforts to overcome it to increase the production and quality of durian fruit. - National Proceedings Seminar on Sustainable Rural Resource Development and Local Wisdom II, 22-23 November, Purwokerto, Central Java, Indonesia.

TRUEMAN S.J., 2011 - Endogenous cytokinin levels during early fruit development of macadamia. - African J. Agric. Res., 5(24): 3402-3407.

WANG K.L.C., LI H., ECKER J.R., 2002 - Ethylene biosynthesis and signaling networks. - The Plant Cell, 14: S131S151.

WORLD HEALTH ORGANIZATION, 2020 - Coronavirus disease (COVID-2019) situation reports. https://www.who.int/emergencies/diseases/novelcoronavirus-2019/situation-reports. 